\title{
An Examination of Educational and Familial Factors in Leadership Development
}

\author{
Abdullah Balikçi \\ Hasan Ali Yücel Faculty of Education, İstanbul University, Beyazit Campus, Turkey
}

Copyright $(2018$ by authors, all rights reserved. Authors agree that this article remains permanently open access under the terms of the Creative Commons Attribution License 4.0 International License

\begin{abstract}
In this study, family attitudes and behaviours, along with educational factors during school years, which are believed to have an effect on the development of leadership, are researched. In the study, the qualitative research method and phenomenological model have been applied. The participants were identified as one female and one male student by means of the snowball and convenience sampling methods. In the study, two fundamental factors, namely the familial and educational factors, were determined as supporting the development of leadership in students. In this context, it was observed that families had a democratic attitude towards their children, that they displayed supportive behaviour towards them, and that they gave them guidance in a healthy communicative environment. As for in schools, it was observed that teachers gave the students duties in educational, social and sporting exercises and that they encouraged them to take part in various activities.
\end{abstract}

Keywords Leadership Development, Student Leadership, Democratic Family, Education and Leadership Development

\section{Introduction}

It is stated that in order to understand the roots of leadership development, certain features of educational, social and family experiences may be effective in both the childhood and youth periods of individuals. In this context, revealing whether or not family attitude, participation in school activities and social skills are effective in leadership development may contribute towards a better understanding of leadership development [29]. Therefore, by revealing experiences of the school years, family attitudes and learning that may have an effect on leadership development, certain findings may be presented with regard to the experiences and varieties of the first years of life.

With regard to leadership qualities, researchers have tended to focus on managers or individuals from business life. In this context, leadership qualities such as achievement, patience, perception, entrepreneurship, self-confidence, sociability, consistency and extroversion have been determined [31]. In these studies, qualities commonly possessed by effective leaders are stated to be personality, competence and motivation. In effective leadership, self-confidence, ability to cope with stress, emotional maturity and consistency in behavioural values are important [21]. On the other hand, during the school years and student period, too, individuals possess certain leadership qualities. Among these are respect, service, honesty, skill, passion, learning, empathy, attitude, dedication and energy [38]. Besides these, the following leadership qualities have been determined as observable in students: (i) Desire to compete (ii) Ability to solve problems creatively (iii) Capacity for critical reasoning (iv) Skill in seeing new relationships (v) Ease of articulation (vi) Flexibility of thought and movement (vii) Tolerance for uncertainty (viii) Ability to motivate others [38].

It may be stated that various factors will be effective in bringing out the aforementioned leadership qualities of individuals. Among these factors may be counted school studies and teacher and family support. First of all, teachers may assist in the development of students' leadership skills. Activities such as workshops and book reading classes are important [6]. School and in-class and out-of-class activities that will enable the development of leadership in students may be concentrated on in classrooms [23, 32, 36].Secondly, family attitude is seen to be important for the development of leadership in students. Children of democratic families have been found to have higher levels of the leadership qualities that underlie their problem-solving capacities than do children of authoritarian families [16]. In children of authoritarian families, however, social skills have been found to be low and communication skills to be weak [4, 29]. Positive relationships between emotional autonomy, mastery of tasks, and transformational leadership qualities have been found in children of authoritative families [24]. As can be understood from these statements, revealing the effects of 
the experiences of the school years and family environment on leadership development are seen to be important. Making sense of these factors may be helpful in understanding leadership development. At the same time, in the national literature, empirical studies exist that aim to reveal leadership qualities $[3,5,9,12,20]$, how these may be developed [34] and the factors that affect leadership development [7, 19], as do studies that deal with scale adaptation or development [8]. Therefore, it may be said that the number of studies in the national literature is limited. One of the reasons for carrying out this study is that it will contribute to the enlargement of this literature.

According to the above statements, an examination of the activities related with the family attitudes, school experiences and improvement in social skills that can contribute to leadership development may be useful in determining the factors that encourage leadership development. In this context, in this study, the factors that may contribute to leadership development in the lives of one female and one male student at high school level, when leadership qualities come to the fore, have been taken up as the research subject.

\section{Aim}

The aim of this study is to reveal the parenting styles, educational factors and social learning opportunities that are considered to be effective in leadership development of individuals.

\section{Method}

A qualitative approach has been adopted in the study. Qualitative studies are types of research in which qualitative data collection methods such as observation, interviews and examination of documents are used, and in which a procedure is followed that aims to reveal perceptions and events realistically and holistically in a natural environment [41]. As a design, the phenomenological design was selected as suitable for this framework. [10] phenomenology is "a qualitative research method where the researcher attempts to understand and describe how one or more participants experience a phenomenon" (event, situation, concept, etc.). It may be said that two factors are effective in the selection of a phenomenological design. The first is the consideration that the contribution to the research of the experiences of the participants that result from their intense interactions with students in school is compatible with this method. The second is the fact that those working in this field - the researcher also works in this field - and those who have done research by using the design specified express positive views in this direction. In the selection of the study group, since the researcher is also an educator and is familiar with the schools in his area, snowball sampling was used because of convenience sampling and the identification of student leaders by asking 22 teachers working at the high school where the research was conducted in Üsküdar, Istanbul. As a result of this choice of sampling, 2 students were included in the research. Determining the sample size, two factors have been effective. The literature and observational reports are from teachers of 2 students. Firstly, looking at the literature, [36] there is no rule for sample size in qualitative research. Determining the size of the sample goal, agenda, usability, credibility, time and resource are key factors. [27] Sample size may vary according to questions, data and resources. Secondly, the concerned teachers stated that the 2 students have appropriate characteristics for both this research and leadership. [28], convenience sampling "saves time, money and effort but at the expense of information and credibility". The aim of the snowball (chain-referral) strategy is to identify people who are known to have deep knowledge of a certain situation and to ask them to identify other people they know who have knowledge of the same situation. It is considered that the fact that the researcher of the current study is a teacher will reflect positively on the research.

Content analysis was used in the study. [35] content analysis may be evaluated as an effort to reduce and interpret qualitative data with the aim of determining the aspects of the broad data gathered that show basic consistency. In this study, in which the qualitative research approach has been used, the interview method has been used due to its features such as assisting in revealing complex personal and emotional problems, allowing for the required data to be obtained thoroughly and in depth, providing the opportunity for instant feedback to be given to the answers obtained, possessing flexibility in conforming to changes and to conditions that may suddenly change, and allowing for freedom to change the number and order of the questions [22,40]. In order to obtain interview-based data, a semi-structured interview form was created. For this purpose, preliminary interviews were conducted with the 2 students who were planned to be interviewed, and the interview form was reviewed according to the data obtained from this and to whether the questions would serve the designated aim, and after obtaining the views of expert academicians in the field and also those of Turkish teachers, the semi-structured interview form was given its final shape. After the interview form had been finalised, implementation was commenced and notes were taken before the interviews, during the interviews and after the interviews, and after these notes had been approved by the participants, analyses were made. Following the analyses, open coding was performed; from this the categories and themes were formed. [30], open coding is the first coding of qualitative data; the researcher examines the data and summarises them in the form of analytic categories or codes, which serves as a preparatory stage. For the interviews with the students, permission was obtained on both an 
organisational and on a personal level, thereby taking care that no ethical problems were experienced. In addition to the interviews, the observation notes were also utilised in the research. According to [26], in an interview an observer will reveal his/her own knowledge and experience in presenting his/her observations and evaluating the findings. Another contribution of observation to research is to make it possible to exhibit behaviour thoroughly.

As regards the validity and reliability stage of the research, 4 of the strategies defined by [10] have been utilised. These strategies are: extensive field study, variety of data, external auditing and referee evaluation. The implementation of these strategies was carried out as follows:

1. Extensive field study: The national and international literature related with the research area was scanned.

2. Variety of data: Interviews were conducted in relation to the data and observation notes were utilised.

3. External auditing: The research procedure was scrutinised by consultation with experts in this research field and with people conducting research in this area

4. Referee evaluation: Evaluation of the research findings was made by people who have carried out studies in this field.

\section{Results and Comments}

In the study carried out, 2 themes and 6 categories were determined. These were parenting styles and school experiences in student leadership.

\subsection{Parenting Styles}

It is understood that on the subject of student leadership, the family (parents) is one of the factors affecting students. In the research, 3 sub-categories were determined from the data analysis of this theme. These are: showing a supportive attitude, adopting democratic values and accepting healthy communication as a principle.

\subsection{Supportive Attitude}

It can be understood from the opinions of their teachers and the statements of their families that the acquisition of an important quality like leadership on the part of the students, Hale and Emre, who are the subject of this research, was based on the supportive attitudes of their families. The fact that the students felt the support of their parents may stem from the cooperation between the school and the families, the school's and families' awareness of their responsibilities, the students' continuously thinking and behaving towards improving themselves, and the fact that the school and the families "spoke the same language" with regard to the students' education. In other words, the school and the families may have treated the students with an empathic approach. Studies exist in the educational literature that refers to the importance of school-family cooperation and express that success may come through this method. Our observations from the interviews that we made show that there were similar experiences for both students concerning "family". In this context, the students expressed the following common views:

- The mother is educated

- The mother taught good quality things

- The mother constantly took an interest

- The family's financial circumstances were good

- The mother gave support for special skills such as "playing the violin"

- The family was always interested in the student's lessons

- The family brought them up to be responsibility-focused

\subsection{Democratic Values}

It is understood that for the family to give proper values to students, both the school and the family are important in their lives. Giving democratic values may also contribute to the student's socialisation. With regard to the student's showing "leadership" qualities, not being under pressure, being shown that values are given and cared about in the family, and his/her opinions being asked for in decisions affecting the family may be taken into account. To enable the complete transmission of the determined qualities by the family to the student, taking into account the education that the student receives at school may also be beneficial for understanding the reasons underlying the student's behaviour. At the school where the researcher conducted the interviews, in his observations made prior to and following the interviews, the relaxed behaviour of the students and the fact that they mentioned their families in a positive way shows consistency with the gathered data. In this context, the students expressed the following common views:

- At the heart of education, the mother's contribution is great

- During their childhood, the family did not grant their every wish

- The family gave importance to religious ceremonies

- The mother drew a vision for him/her

- The family valued him/her

- The family asked for their opinions on various subjects

- Their fathers intervened in what they did at a limited level

\subsection{Healthy Communication}

With regard to the families' understanding of the students' own duties and responsibilities both inside and 
out of school, it can be seen that the importance of communication they make will also be reflected on their leadership behaviours. A positive situation regarding communication leads to family members caring about each other, trusting each other, and raising the relationships to the desired level. Sometimes situations where emotions are shown in different ways are encountered. In the researcher's interviews with the students, the fact that the students established good and easy communication with their teachers has the characteristic of supporting the findings specified. In this context, the students expressed the following common views:

- The mother was the first person to influence and guide them

- They owed their confidence to their mothers

- They had closer relationships with their fathers

- Their mothers trusted them a lot

- They could speak openly with their mothers

- Communication between family members was strong

\subsection{School Experiences}

It can be clearly understood from the gathered data that on the subject of the students' showing leadership qualities, "school experiences" have undeniable importance. 3 sub-categories for the participants' school experiences were determined following the interviews. These are: students' experiences with school teachers and school administrators, social activities and interactions, and academic success.

\subsection{Teachers' Incentive Approaches}

When considering that after the family, their school and teachers are the place and people that students spend the most time with, the importance of what they gain from there can be understood from the interviews and observations carried out.

A striking part of the data is the fact that in order for the leadership quality to appear, the student's experiences with school teachers and administrators should be at a positive level and should be desired experiences. For example, the fact that a student likes and becomes attached to his/her school and teacher, may be effective in the student's displaying positive behaviours such as leadership. From this it can be better understood how important a place the school, the teachers and administrators have in the lives of individuals, groups and society. The researcher's observations show that the students who took part in the research had better communication with their teachers than did the other students, and that their motivation towards school was greater. The common points in the students' views can be expressed as follows:

- Their primary school education was carried out at a state school and pilot school
- $\quad$ Their teacher in 3rd grade at primary school left a great impression on their development

- Their teacher was very fond of them

- The teachers recommended different books for them to read

- The teachers showed interest in the students

- They loved the lesson when they loved the teacher

- They studied 3 years of primary school at a state school

- Their teacher taught them the violin

- They loved their music teacher

- If they loved the teacher they loved the lesson

- They were dependent on their teachers

- They did not get angry with the principal if he/she was right

- They loved the teachers who showed interest in them

- They believed that interaction was important in education

\subsection{Social Activities and Interactions}

The student's participation in social activities at school and his/her social relations affect the development of his/her character which is important for leadership. In the modern understanding of education, the concept of "success" is not confined only to the lesson, to the academic aspect, but has come to include the student's participating in various activities and communicating with various people, and therefore the skills that are acquired or are to be acquired by students determined as "student leaders" have come to be even more important. In the sense of being a leader, it may be said that the social behaviours and skills expected from student leaders are doing teamwork with their friends, ensuring active participation in organisations, showing behaviours that give attention to values, the ability to acquire self-confidence and self-discipline, and displaying tasks and behaviours that are beneficial to society. The research by the researcher into the number of activities and organisations taken part in by participating students and their duties - the relevant data were obtained from the school administrators - shows correspondence with the specified findings. The common points in the views of the participating students related with this subject may be expressed as follows:

- Developing oneself and serving the community

- Attending concerts

- Active participation in societies

- Distinguishing oneself in competitions

- Having relationships with different groups of friends

- Getting on well with the school administrators

- Having a great skill for leadership

- Being responsible towards others

- Having a good level of communication

- Trying to correct errors 
- $\quad$ Ease of communication

- Easily expressing one's opinions

- Organising various conferences

- Attending clubs

- Writing articles in magazines

- Being together with people and helping them

- $\quad$ Listening to others, but preferring to direct them

- Not remaining unaware of social events

\subsection{Academic Success}

It can be understood from the data that academic success, which is the first thing that comes to mind and is looked at when success is mentioned, is also important for and given importance by student leaders. It is believed that academic success both facilitates healthy communication and paves the way for a student to love his/her school, teacher and school administrators. Besides this, various factors (negative experiences such as exam stress and loss of various gains) are experiences that are feared by student leaders just as they are by other students. These experiences, which are considered to have negative results, affect students. Yet the fact that a student's academic stress, with the trust in the school, teacher and school principal mentioned above, can be surmounted with a positive approach is reflected in the views of the participants. When the researcher asked teachers at the school of the students considered as student leaders by the participants about the points concerning their lessons that they did not understand, the observation that they consulted the people (school administrators, teachers, school staff) related with the situations that concerned themselves shows that there is correlation with the data. In this context the students expressed these views:

- They wanted a good education

- The fact that the OKS (national high school placement exam) exam went badly had a saddening effect on them

- High school was effective in showing them the way

- They believed that education should transport people to certain places

- They were interested in reading and writing

- They wanted to learn a lot

- They objected to studying to the point of being asocial

- They were afraid that their scholarships from exams would be cut

- Excessive stress developed in them due to exams

\section{Conclusions, Discussion and Suggestions}

According to the research, it was revealed that there are two principal factors that nurture leadership development in individuals. The first of these are gains made by individuals from the lives that they live with the family mainly outside school life. It is understood that receiving support from the family, acquiring certain values, open communication and democratic behaviours contribute to leadership qualities in individuals. In similar studies by $[2$, 14, 33], it was determined that the family, school management and teacher had a direct effect on student success. Consistent, open and supportive families ensure the development of positive self-perspective and a sense of transformational leadership develops in the individual who becomes a valuable member of the family [18].

According to the research, the other aspect that supports leadership in individuals is the experiences gained in school. Influenced by their teachers and the activities carried out in class, individuals strengthen their leadership qualities. In their study, [25] stated that on the subject of students' leadership development, the positive relationships formed with their friends and outside class made a positive contribution to students' development. On the other hand, it is stated that in terms of the student's psychological and academic needs, being in communication with the school principal and teacher is important from the viewpoint of organising the student's own lifestyle and increasing his/her competences [1, 37]. In a study conducted, it was observed that students' participation in activities inside and outside class increased students' leadership skills by approximately $25 \%$ [39].On the other hand, these activities bring about acceptance of social values by developing interpersonal skills and gaining social skills [17]. At the same time, self-discipline, motivation and rivalry increase out-of-class activities [13]. The school management also has an effect in bringing out students' leadership behaviours. According to [11], the fundamental role of school administrators with regard to student leadership is to accompany his/her development, control his/her development, and give support and encouragement.

With reference to the above results, since it is observed that familial and educational factors are important in the development of leadership in individuals, conducting of studies in the direction of raising awareness in families and educators may be suggested. Besides, activities that support leadership development of students in schools may be given priority. Leadership development may be considered as a whole and studies related with activities in schools and family attitudes may be planned with larger study groups. As for policy makers, they may give schools more independence in the planning of practices that will support leadership development in both the curriculum and in-school practices.

\section{REFERENCES}

[1] C. M., Adams, J.J. Olsen, J.K. Ware. The school principal 
and student learning capacity, Educational Administration Quarterly, 53(4), pp. 556- 584, 2017.

[2] S. Akbaşlı. Ortaöğretim okullarındaki okul aile birliklerinin görevlerini gerçekleştirme düzeyleri (Konya ili örneği) (Yayınlanmamış doktora tezi). Hacettepe Üniversitesi, Ankara, 2007

[3] B. Avcı. Öğrencinin liderliği (Yayınlanmamış yüksek lisans tezi). Gaziosmanpaşa Üniversitesi Sosyal Bilimler Enstitüsü, Tokat, 2009.

[4] D. Baumrind. The influence of parenting style on adolescent competence and substance use, Journal of Early Adolescence, 11(1), 56-95, 1991.

[5] Z. H. Birol. Fen lisesi ve sosyal bilimler lisesi öğrencilerinin mükemmelliyetçilik, benlik saygısı, liderlik özelliklerinin incelenmesi (Yayımlanmamış yüksek lisans tezi). Karadeniz Teknik Üniversitesi, Trabzon, 2005.

[6] A. Bisland. Developing leadership skills in young gifted students, Gifted Child Today, 27(1), 24, 2004.

[7] R. Cansoy. The effectiveness of leadership skills development program for university students, Journal of History Culture and Art Research, 6(3), 65-87, 2017.

[8] R. Cansoy, S. Turan. Gençlik liderlik özellikleri ölçeği: güvenirlik ve geçerlik çalışması, Türkiye Eğitim Dergisi, 1(1), 19-39, 2016.

[9] R. Cansoy, M. E. Türkoğlu, \& H. Parlar. Liderlik özellikleri: bir ölçek geliştirme çalışması ve öğrencilere yönelik bir araștırma, Milli Eğitim Dergisi, 212, 139-159, 2016.

[10] L. B. Christensen, R. B. Johnson \& L. A. Turner. Nitel ve karma yöntem araştırmaları (M. Sever, Çev.), (A. Aypay, Çev. Ed.) Araștırma yöntemleri desen ve analiz (400-433). Ankara: Anı, 2015.

[11] A. Coffey, S. Lavery. Student leadership in the middle years: a matter of concern, Improving Schools, 1-14, DOI: $10.1177 / 1365480217732223,2017$.

[12] C. Çelik, Ö. Sünbül. Liderlik algılamalarında eğitim ve cinsiyet faktörü: Mersin ilinde bir alan araştırması, Süleyman Demirel Üniversitesi İktisadi ve İdari Bilimler Fakültesi Dergisi, 13 (3), 49-66, 2008.

[13] N. Darling, L. L. Caldwell, R. Smith. Participation in school-based extracurricular activities and adolescent adjustment, Journal of Leisure Research, 37(1), 51-76, 2005 .

[14] M. Dinçer. A study on the dynamics of parent satisfaction and student academic achievement at schools using system dynamics modeling (Yayınlanmamış doktora tezi). Yeditepe Üniversitesi, İstanbul, 2015.

[15] Ö. Durmuş. İlköğretim ve lise öğrencilerinde görülen liderlik davranışlarının araştırılması (Yayınlanmamıs yüksek lisans tezi). Çanakkale Üniversitesi, Çanakkale, 2011

[16] S. Düzakın. Lise öğrencilerinin problem çözme becerilerinin bazı değişkenler açısından incelenmesi (Yayımlanmamış yüksek lisans tezi). Gazi Üniversitesi, Ankara, 2004.

[17] J. S. Eccles, J. Templeton. Extracurricular and other after-school activities for youth, Review of Research in Education, 26, 113-180, 2002.

[18] D. W. Guerin, ,P. H. Oliver, A. E. Gottfried, A. W. Gottfried, R. J., Reichard, \& R. E.Riggio. Childhood and adolescent antecedents of social skills and leadership potential in adulthood: Temperamental approach/withdrawal and extraversion, The Leadership Quarterly, 22(3), 482-494, 2011.

[19] H. B. Gündüz, A. Duran. Okul öncesinde liderlik eğitimi: geleceğin liderleri eğitim programının etkililiği, International Online Journal of Educational Sciences, 8 (1), 245-26, 2016

[20] A. Güneş. İlköğretim çağındaki üstün yetenekli öğrencilerle normal gelişim gösteren öğrencilerin liderlik becerilerinin karşılaştırılması: Kırşehir ili örneği (Yayımlanmamış yüksek lisans tezi). Erciyes Üniversitesi, Kayseri, 2010.

[21] W. K. Hoy, C. G. Miskel. Okullarda liderlik. (S. Turan, Çev.), (S. Turan Çev. Ed.), Eğitim yönetimi: teori, araştırma ve uygulama (s. 374-410). Ankara: Nobel, 2010.

[22] N. Karasar. Bilimsel araştırma yöntemi, Ankara: Nobel Yayıncılık, 2000.

[23] F. A. Karnes, S. M.Bean. Developing leadership in gifted youth (Report No. EDO-EC-90-4). Washington, DC: Office of Educational Research and Improvement, 1990.

[24] F. T. Kudo, J. L. Longhofer, J. E., Floersch. On the origins of early leadership: the role of authoritative parenting practices and mastery orientation, Leadership, 8(4), 345-375, 2012.

[25] S. B.Marcketti, S. W. Arendt, M. C. Shelley II. "Leadership in action: student leadership development in an event management course", Leadership \& Organization Development Journal, 32, 2, pp. 170-189, https://doi.org/10.1108/01437731111112999, 2011.

[26] S. B. Merriam. Dikkatli bir gözlemci olmak, (H. Özen, M. Yalçın, Çev.), (S.Turan, Çev. Ed.) Nitel araştırma yöntemleri (111-130). Ankara: Nobel, 2015.

[27] S. B. Merriam. Araştırmanın desenlenmesi ve örneklem seçimi, (S. Turan, D. Yllmaz, Çev.), (S.Turan, Çev. Ed.) Nitel araştırma yöntemleri (55-82). Ankara: Nobel, 2013.

[28] M. B. Miles, A. M. Huberman. Veri toplamaya odaklanmak ve veri toplamayı sinırlamak: anlamlı bir başlangıç (D. Örücü, Çev.), (S. Akbaba Altun, A. Ersoy, Çev. Ed.) Nitel veri analizi (16-39). Ankara: PegemA, 2015.

[29] S. Murphy, S. Johnson. The benefits of a long-lens approach to leader development: understanding the seeds of leadership, Leadership Quarterly, 22(3), 459-470, 2011.

[30] L. W. Neuman. Toplumsal araştırma yöntemleri, (Çev. Özge, S.). İstanbul: Yayın Odası, 2010.

[31] P. G. Northouse. Leadership: theory and practice. Sage Publications, California, 2004.

[32] Ü. Ogurlu. Liderlik becerileri geliştirme programının üstün zekalı olan ve olmayan ögrencilerin liderlik becerilerine etkisi (Yayımlanmamış doktora tezi). İstanbul Üniversitesi, İstanbul, 2012.

[33] M. Özbaş.. İlköğretim okulu yöneticilerinin okul-aile ilişkileri konusunda yapmaları gereken ve yapmakta 
oldukları işler (Yayınlanmamış doktora tezi). Hacettepe Üniversitesi, Ankara, 2009.

[34] H. Parlar, M. E. Türkoğlu, R. Cansoy. Leadership development in students: teachers' opinions regarding activities that can be performed at schools, Universal Journal of Educational Research 5(2), 217-227, 2017.

[35] M. Q. Patton. Qualitative research and evaluation methods. Thousand Oaks, CA: Sage Publications, 2002.

[36] M. Q. Patton. Nitel araştırma tasarımı. (B. Tarman, M.F. Yiğit, Cev.), M. Bütün, S. B. Demir (Cev. Ed.), Nitel araştırma ve değerlendirme yöntemleri (s. 209-258). Ankara: PegemA, 2014.

[37] S. Redmond, P. Dolan. Towards a conceptual model of youth leadership development, Child, Family Social Work, 2014.
[38] H. S. Shin, C. L. Slater, E. Backhoff.. Principal perceptionsand student achievement in reading in Korea, Mexico, and the United States: educational leadership, school autonomy, and use of test results, Educational Administration Quarterly, 49(3), pp. 489-527, DOI: 10.1177/0013161X12458796, 2012.

[39] B. Tüysüz. Öğrenci liderliği programının 6.sınıf ögrencilerinin liderlik rolleri ve davranışlarına etkisinin incelenmesi (Yayımlanmamış doktora tezi). Marmara Üniversitesi, İstanbul, 2008.

[40] J. L. O. Vickers. Relationships between leadership skills and future homemakers of America activities, other leadership development activities, selected student, family and other characteristics Available from ProQuest Dissertations \& Theses Global (Umi No: 304128241), 1994.

[41] A. Yıldırım, H.Şimşek. Sosyal bilimlerde nitel araştırma yöntemleri, Ankara: Seçkin Yayıncılık, 2008. 